[Vicino Oriente XXIII (2019), pp. 47-58]

\title{
QALET HAMRA: A MAMLUK KHAN NORTH OF ZARQA, JORDAN
}

\author{
Lorenzo Nigro - Daria Montanari - Sapienza University of Rome \\ Romeel Gharib - Ministry of Tourism and Antiquities of the Hashemite Kingdom of Jordan
}

The site of Qalet Hamra was well known in Zarqa but it never attracted archaeologists and surveyors until a few years ago, possibly due to its location on a spur dominating the bifurcations between Wadi az-Zarqa and Wadi Shomar, a sort of shortcut leading straight ward to the west, in direction of the Jordan Valley. Moreover it was nearby a major ford across the river, which both banks were caravan tracks in antiquity. In 2015 and 2018 Sapienza University of Rome and the Department of Antiquities of Jordan surveyed, which allowed to identify it as a small caravanserai dating back from the Mameluk period, even though earlier pottery finds may suggest that the site was occupied at least from the Late Roman/Early Byzantine times.

Keywords: Mamluk Sultanate; Zarqa; Qalet Hamra; Haji; khan, Jordan

\section{HISTORICAL FRAME}

After the conquest by the Mamluks of the Ayyubid States in 1263 AD, Transjordan was divided on two provinces, the northern one from Damascus to Wadi Mujib, and Kerak, the southern one, from Wadi Mujib to 'Aqaba (fig. 1). They were secured by means of restoration of Crusader/Ayyubid castles, building roads, and renovating holy places. In facts, Ayyubid administrative and defensive systems were inherited by the Mamluk Sultanate, troubled by the advance of the Mongol power from East. ${ }^{1}$

Ayyubid and Mamluk architectural features range from holy sites to fortified strongholds, typically town-based castles and fort/khans, from agricultural or industrial establishments to rural villages, in a period of reconstruction and renovation after Crusader debacle. $^{2}$

After Crusaders, in facts, social and economic reconstruction of Jordan was concentrated on arboriculture and commercial crops, such as sugar. During Mamluk period (1263-1517 AD), the number of sites increased and a moderate prosperity based on rural economy started, specially thank to the tropical climate of Jordan Valley. ${ }^{3}$ According to alMaqdisī the region of Wadi az-Zarqa was populated by many villages and produced olives, various fruits, grapes, and honey. ${ }^{4}$ Between Zarqa and Wadi al-Mujib were villages, farms, grain-fields, mills. ${ }^{5}$

In the modern city of Zarqa, moreover, Middle Islamic architecture is documented by the small fort of Qasr Shebib, dating back to the thirteenth century, an Ayyub foundation, probably on a preceding Roman fort or square tower, well-known in Mamluk period. ${ }^{6}$

\footnotetext{
Walmsley 2001, 521; Walker - Dotti - Nucciotti 2009, 126-127; Walker 2011.

Walmsley 2001, 527; Walker 2008; Walker - Dotti - Nucciotti 2009, 128-129.

Kafafi et al. 2000, 706; Munzi et al. 2000, 386; Palumbo et al. 2002, 144-145.

Le Strange (transl.) 1886, 56; Walmsley 2008, 4.

Walmsley 2001, 515-517, 523, 541.

Petersen 1991; Walmsley 2001, 530.
}

ISSN 0393-0300

e-ISSN 2532-5159

Rivista Open Access 


\section{THE KHAN}

Qalet Hamra was in the southern sector of the Damascus' province and stood in a hinge area, along the border between Cairo and Damascus, ${ }^{7}$ in the region named Balqa in the Medieval Islam, ${ }^{8}$ between Wadi az-Zarqa and Wadi al-Mujib. Zarqa, a defensive post together with Ajlun, Shawbak and Kerak, was an important stop for pilgrims already in the late twelfth and thirteenth centuries. ${ }^{9}$

The building is in the suburb of Shomar, just north to the modern city of Zarqa $\left(32^{\circ} 05^{\prime} 00.7^{\prime \prime} \mathrm{N} 36^{\circ} 03^{\prime} 55.5^{\prime \prime} \mathrm{E}\right)$. It rises directly next to the joint between Wadi Shomar and Wadi Zarqa, at roughly $70 \mathrm{~m}$ west of it (fig. 2).

That building was reasonably erected in this place due to its vicinity to the cross of Wadi Zarqa and Wadi Shomar tracks, a shortcut used during centuries to reach es-Salt and then the Jordan Valley to the west. ${ }^{10}$ So, it is an ideal location for two of main enterprises during the Mamluk period: rural exploitation and agricultural production, along the pilgrimage route. ${ }^{11}$ In this perspective, the khan of Qalet Hamra should host traveling pilgrims and manage the cultivated land along the river banks, usually entrusted to military officers as grant tax in this period. ${ }^{12}$

The khan consists of two buildings (fig. 2). The bigger one had a pristine square plan $(10 \times 10 \mathrm{~m})$ subdivided into two rectangular rooms $(4 \times 8 \mathrm{~m})$ at the ground floor, covered by two vaults (figs. 3-6), and in more rooms in the first floor. This square structure was set on the top of the spur dominating the ford across the Zarqa river and the joint of it with Wadi Shomar. In front of the original building there was a fenced courtyard, and on the opposite eastern side there was a subsidiary building - one storey high - possibly serving as stable for animals. The original khan was expanded by adding another couple of rectangular rooms to the south, one of the two further subdivided into two square rooms. This structure was partly built on the slope south of the top of the spur where the original building stood. A further rectangular piece was added to the north, so that the whole western side of the square precinct of the caravanserai was occupied by buildings. In the north-eastern corner of the courtyard there was a cistern, while on the northern side of the hill, rock terraces gently sloped down to the river banks.

It is very difficult to establish the chronology of the constructive phases of the khan in absence of proper excavations. An original occupation of the site in the early Islamic period is suggested by some pottery fragments, ${ }^{13}$ while the main building can be dated to the Mamluk period with a later addition in the early $15^{\text {th }}$ century AD.

Munzi et al. 2000, 386; Walker 2013, 184-187.

Sourdel-Thomine 1979 .

Walker 2013, 184-187.

Nigro - Gharib 2016, 59

Already in the Ayyubid period, in the area of Zarqa, fortress and watchtower performed different functions (Milwright 2006, 9). Moreover, a dual purpose is already certified for some Levantine khan (Lee et al. 1992, 57-60).

12 Walker 2003, 244; Walker - Dotti - Nucciotti 2009, 126-127.

13 See QH.15.0/1 in fig. 7. 
The building probably was destroyed by a seismic swarm that struck the region between the late fourteenth century and the beginning of the fifteenth century, ${ }^{14}$ and after that abandoned.

Over the centuries the khan has been looted and used as a quarry for building material, and, in recent times, it unfortunately suffered illegal excavations.

The date suggested to the Mamluk period for the khan is based on geographical information (pilgrimage itineraries) and pottery (fig. 7) collected during the survey of 2015, combined with a territorial study of the Middle Islamic period and a comparative analysis with other forts and khans. ${ }^{15}$

As it concerns pottery, the repertoire is represented by unglazed wheel-made ware, ${ }^{16}$ used mainly for storing, preparing, transferring and serving food, as jars and jugs. QH.15.0/2 is a wall of a sugar pot, typical of Mamluk period, characterized by a conical body with an outward folded rim, narrow base, rounded or flat base, ribbed on the exterior. $^{17}$

\section{THE KHAN IN THE HAJI PILGRIMAGE}

The pilgrimage route from Damascus to Mecca passed through Zarqa in the way to Amman, which was a major assembly place for pilgrims from Palestine and continued southward (fig. 8). ${ }^{18}$ From Damascus the caravan route made two stops before Busra, after travelled to the Pool of az-Ziza and, then, the most suitable track to the south-east was through Zarqa. ${ }^{19}$

A series of khan and fortresses were displaced along such a route were progressively built during the Ayyubid and Mamluk periods. One of this major forts and towers was, in the Wadi az-Zarqa, Qasr Shebib. Mamluks, in facts, were interested in securing the major roads and the postal network. ${ }^{20}$ Caravanserais were erected at major crossing points, especially by fords and rivers, where usually postal stations were established. ${ }^{21}$

Qasr Shebib was a Mamluk fort along the Haji, ${ }^{22}$ and, as already pointed out by Petersen it is quoted variously in Ottoman sources. J.L. Burkchardt was the first European to describe the Qasr Shebib, at the beginning of the $19^{\text {th }}$ century, ${ }^{23}$ and he wrote:

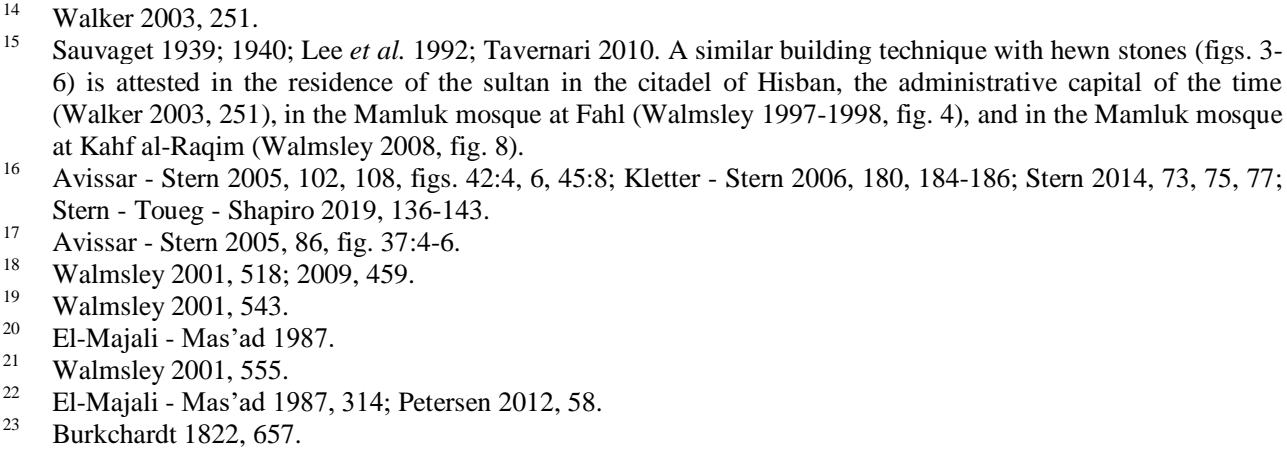

Sauvaget 1939; 1940; Lee et al. 1992; Tavernari 2010. A similar building technique with hewn stones (figs. 3 6) is attested in the residence of the sultan in the citadel of Hisban, the administrative capital of the time (Walker 2003, 251), in the Mamluk mosque at Fahl (Walmsley 1997-1998, fig. 4), and in the Mamluk mosque at Kahf al-Raqim (Walmsley 2008, fig. 8).

16 Avissar - Stern 2005, 102, 108, figs. 42:4, 6, 45:8; Kletter - Stern 2006, 180, 184-186; Stern 2014, 73, 75, 77; Stern - Toueg - Shapiro 2019, 136-143.

Avissar - Stern 2005, 86, fig. 37:4-6.

Walmsley 2001, 518; 2009, 459.

Walmsley 2001, 543.

El-Majali - Mas'ad 1987.

Walmsley 2001, 555.

El-Majali - Mas'ad 1987, 314; Petersen 2012, 58.

Burkchardt 1822, 657. 
«The Hadji rests here one day, during which the Hadjis amuse themselves with hunting wild boars which are found in great numbers on the reedy banks of Wady Zerka. The castle is built in a low wadi wich forms in winter-time the bed of a river of considerable size, called Naher Ezzerqa, whose water collect to the south of Djebel Haouran. In the summer the Wadi to the E. of the castle has no water in it, but to west where there are some sources, the river is never completely dried up».

Qasr Shebib stands on a higher spur in respect of Qalet Hamra (fig. 9), and it also is far away from the river banks. Conversely, Qalet Hamra lays about $100 \mathrm{~m}$ far from the river banks, being an ideal watering place for caravans. Moreover, the Zarqa River flows to west of Qasr Shebib, and not to the east as it seems to be described by Burkchardt. On the contrary, Qalet Hamra lays east of the river, in a location which fits perfectly Burkchardt's description.

Furthermore, local scholars which describe Qasr Shebib $^{24}$ tell that pilgrims during Mamluk period use to camp outside of the qasr in the river valley and this might suggest along with the above mentioned Burkchardt's description - that the site used to stop was that of Qalet Hamra.

\title{
REFERENCES
}

\author{
AVISSAR, M. - STERN, E.J. \\ 2005 Pottery of the Crusader, Ayyubid and Mamluk Periods in Israel (Israel Antiquities \\ Authority 26), Jerusalem 2005. \\ BURKCHARDT, J.L. \\ $1822 \quad$ Travel in Syria and the Holy Land, London 1822. \\ Kafafi, Z. - Matthiae, P. - Al-Shyiab, A.H. - Parenti, F. - Santucci, E. - Benedettucci, F. - Al- \\ Khadi, N. - Munzi, M. - Palumbo, G. - Peruzzetto, A. - Wilson, M. \\ 2000 The Zarqa Valley in Jordan from Lower Paleolithic to recent times: results of the 1993- \\ 1997 Campaigns: P. Matthiae - A. Enea - L. Peyronel - F. Pinnock (eds.), Proceedings \\ of the First International Conference on the Archaeology of the Ancient Near East. Rome, \\ May $18^{\text {th }}-23^{\text {rd }} 1998$, Rome 2000, pp. 699-708. \\ KLETTER, R. - STERN, J.E. \\ 2006 A Mamluk-Period Site at Khirbat Burin in the Eastern Sharon: 'Atiqot 51 (2006), pp. 173- \\ 214. \\ LeE, M. - Raso, C. - Hillenbrand, R. \\ 1992 Mamluk caravanserai in Galilee: Levant 24 (1992), pp. 55-94. \\ LE STRANGE, G. (transl.) \\ 1886 Description of Syria, including Palestine by Mukaddassi (CIRC. 985 A.D.) (Palestine \\ Pilgrims' Text Society), London 1886. \\ EL-MAJALi, R. - MAS'AD, A. \\ 1987 Trade and trade route in Jordan in Mamluke era (AD 1250-1516): Studies in the History \\ and Archaeology of Jordan 3, pp. 311-316.
}

24 El-Majali - Mas'ad 1987, 314, Petersen 2012, 61 
MiLWRight, M.

2006 Central and Southern Jordan in the Ayyubid Period: Historical and Archaeological Perspectives: Journal of the Royal Asiatic Society 16/1 (2006), pp. 1-27.

Munzi, M. - Bianchi, B. - PeruzZetto, A. - WiLson, M.D.

2000 Ricognizioni nell'alta valle del Wadi az-Zarqa, Giordania centro-settentrionale: dall'età romana all'Islam: Archeologia Medioevale XXVII (2000), pp. 377-390.

NigRO, L. - GHARIB, R.

2016 Jamaan at the Pass of Bi'rein. An Iron Age II B-C Ammonite Stronghold in Central Jordan: Vicino Oriente XX (2016), pp. 59-84.

Palumbo, G. - Kafafi, Z. - Parenti, F. - Munzi, M. - Benedettucci, F. - Bianchi, B. - Caneva, I. PeruZzetTo, A. - Wilson, M.

2002 The Joint Italian-Jordanian Project in the Zarqa Valley: Results of the 1993-2002 Seasons: Civiltà del passato, dialogo del presente: missioni di ricerca italiane in Giordania. Civilization of the Past, Dialog of the Present: Italian Research Mission in Jordan, Amman 2002, pp. 131-151.

PETERSEN, A.D.

1991 Two forts on Medieval Hajj route in Jordan: Annual of the Department of Antiquities of Jordan 356 (1991), 347-359

2012 The Medieval and Ottoman Haji route in Jordan. An Archaeological and Historical Study (Levant Supplementary Series 12), Oxford - Oakville 2012.

SAUVAGET, J.

1939 Caravansérails syriens du Moyen Age. Caravansérails Ayyūbides: Ars Islamica 6 (1939), pp. 48-55.

1940 Caravansérails syriens du Moyen Age. Caravansérails Mamelouks: Ars Islamica 7 (1940), pp. 1-19.

SOURDEL-THOMINE, J.

1979 al-Balka: Encyclopaedia of Islam, 2d ed., vol. 1, Leiden 1979, p. 997.

STERN, E.J.

2014 The Crusader, Mamluk and Early Ottoman period pottery from Khirbat din'ila: typology, chronology, production and consumption trends: 'Atiqot 78 (2014), pp. 71-104.

STERn, E.J. - TOUEG, R. - SHAPIRO, A.

2019 Mamluk and Early Ottoman Pottery from Ramla: Defining Local and Imported Fabrics: 'Atiqot 96 (2019), pp. 129-170.

TAVERNARI, C.

2010 Medieval road caravanserais in Syria: an archaeological approach: P. MATTHIAE - F. PINNOCK - L. NigRo - N. MARCHETTI (eds.), Proceedings of the 6th International Congress on the Archaeology of the Ancient Near East, May, 5th-10th 2009, "Sapienza" Università di Roma, Rome 2010, pp. 191-205.

WALKER, B.J.

2003 Mamluk Investment in Southern Bilād Al-Shām in the Eighth/Fourteenth Century: The Case of Hisbān: Journal of Near Eastern Studies 62/4 (2003), pp. 241-261.

2008 The role of agriculture in Mamluk-Jordanian power relations: B. WALKER - J-F. SALLES (eds), Le pouvoir à l'âge des sultanats dans le Bilād al-Shām. Séminaire IFPO-ACOR, Amman 15-16 mai 2005 (Bulletin d'études orientales 57, Supplement), Damas 2008, pp. 77-99.

2011 Jordan in the Late Middle Ages: Transformation of the Mamluk Frontier (Chicago Studies on the Middle East), Chicago 2011.

2013 Ayyubid and Mamluk Jordan: M. AвABSA (ed.), Atlas of Jordan. History, Territories and Society (Contemporain publications 32), Beyrouth 2013, pp. 184-187. 
WALKER, B. - DOTTI, F. - NuCCIOTTI, M.

2009 Shawbak e la transgiordania mamelucca: G. VANNINI - M. NuCCIOTTI (edd.), Da Petra a Shawabak. Archeologia di una Frontiera. Firenze, 13 luglio - 11 ottobre 2009, Prato 2009, pp. 126-141.

WALMSLEY, A.G.

1997-1998 Settled life in Mamlûk Jordan. Views of the Jordan Valley from Fahal (Pella): Aram 9-10 (1997-1998), pp. 129-143.

2001 Fatimid, Ayyubid and Mamluk Jordan and the Crusader Interlude: B. MACDonALD - R. ADAMS - P. BIENKOWSKI (eds.), The Archaeology of Jordan (Sheffield Academic Press), Sheffield 2001, pp. 515-559.

2008 The Middle Islamic and Crusader Periods: R.B. ADAMs (ed.), Jordan: an Archaeological Reader, London 2008, pp. 495-537.

2009 Roads, Travel, and Time 'Across Jordan' in Byzantine and Early Islamic Times: Studies in the History and Archaeology of Jordan 10, pp. 459-466. 


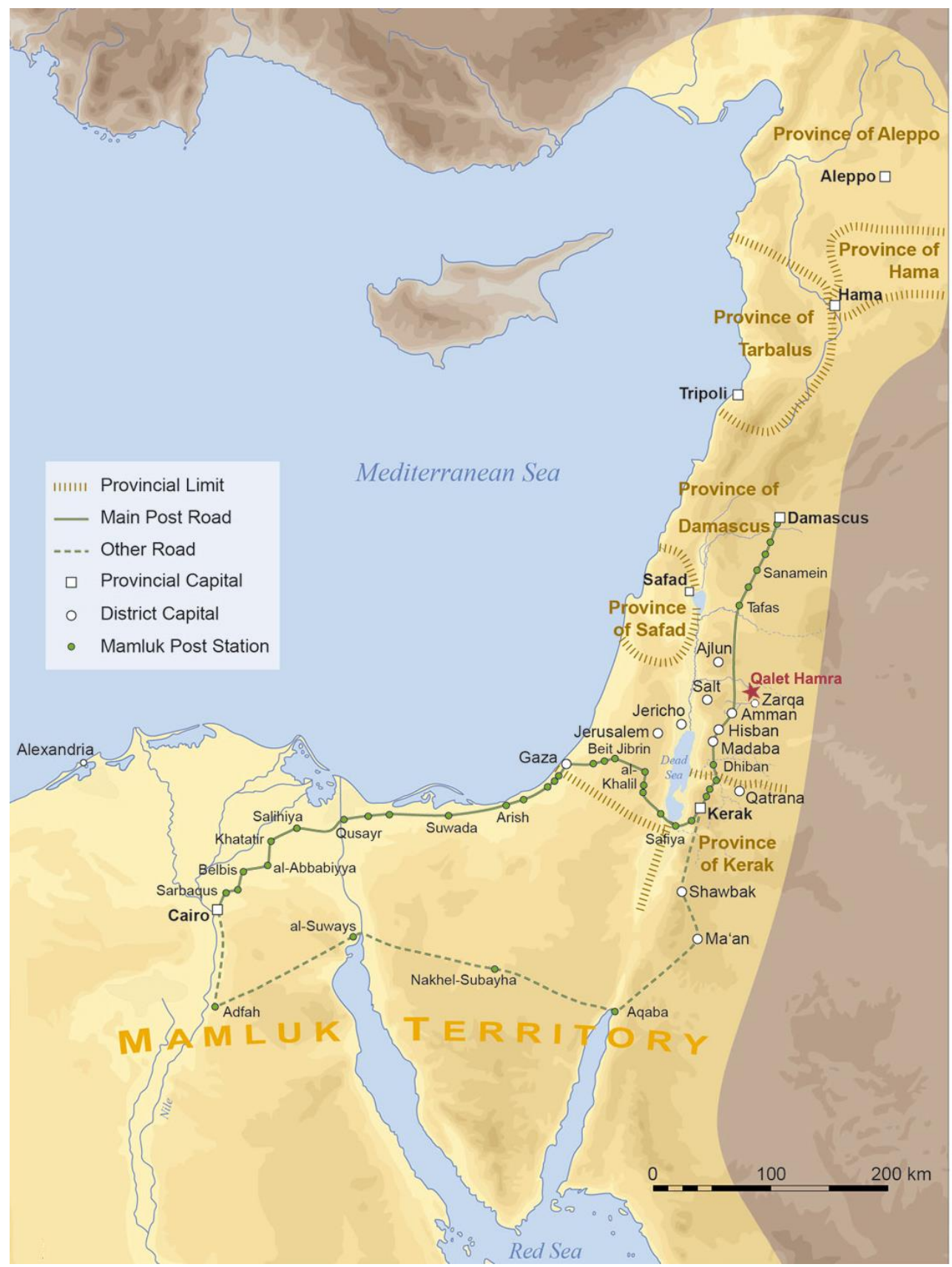

Fig. 1 - Map of Mamluk state (after Walker 2013, fig. 1). 


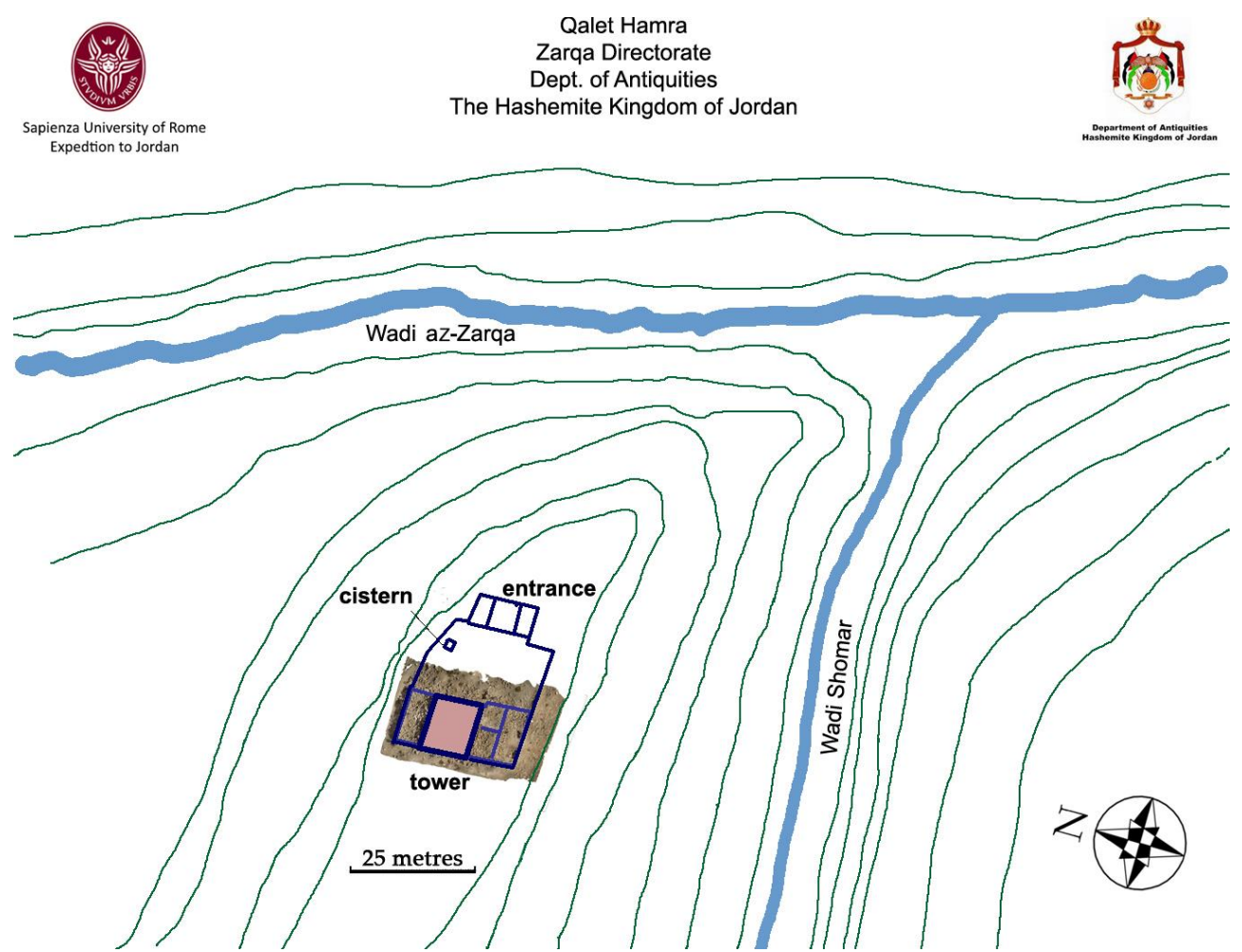

Fig. 2 - Reconstructive plan of the khan of Qalet Hamra superimposed on the orthophoto.

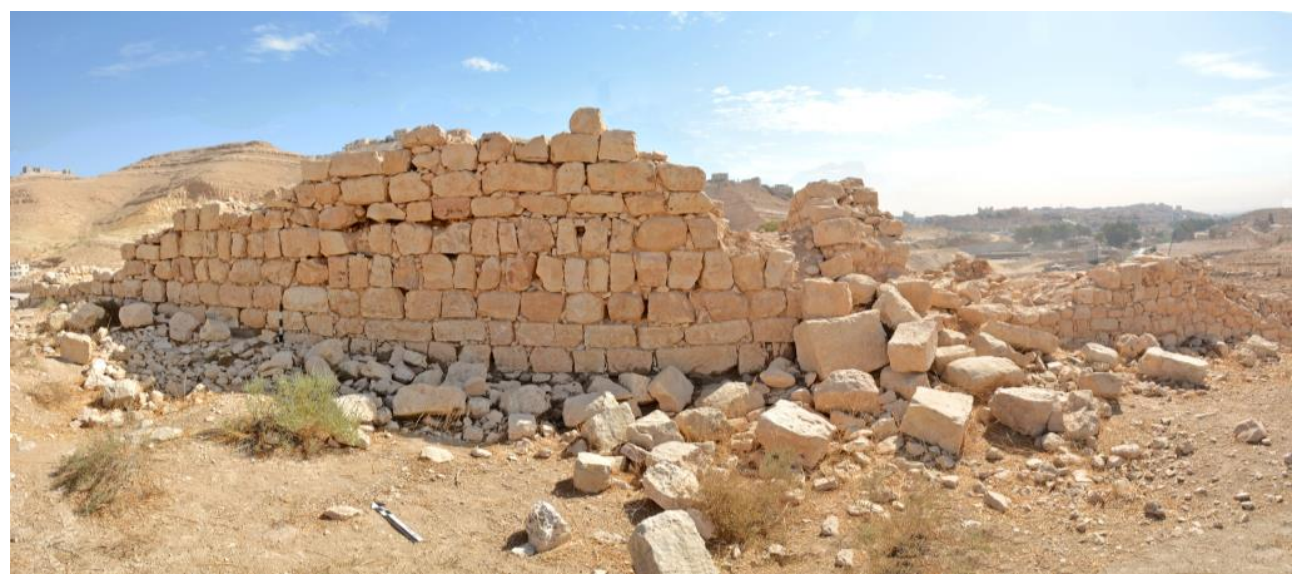

Fig. 3 - The collapsed south-eastern corner and the eastern wall of the khan. 


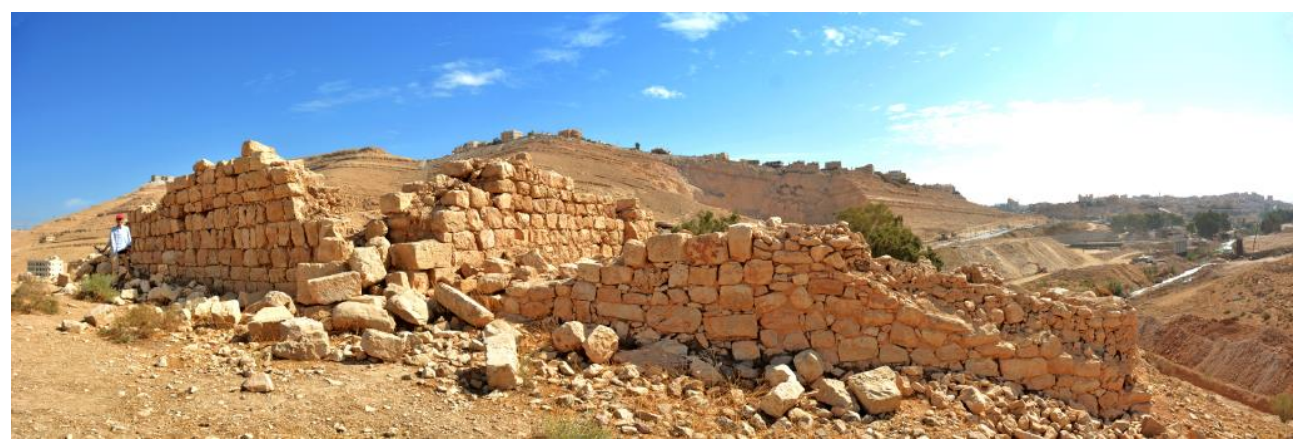

Fig. 4 - The southern wall of the khan.

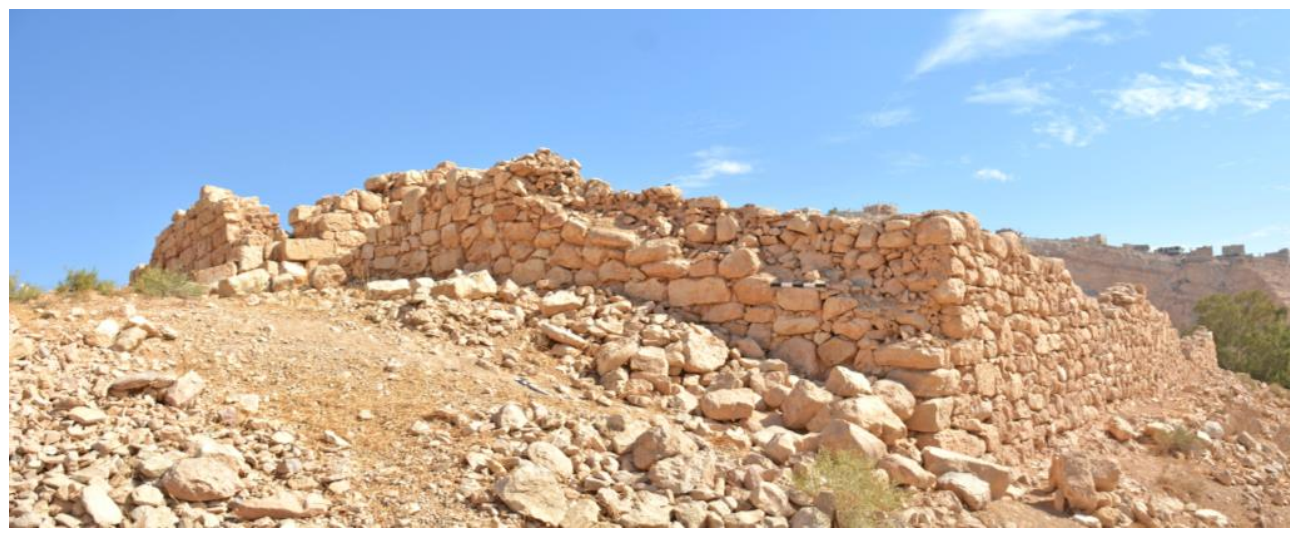

Fig. 5 - The southern wall and the south-western corner of the khan.

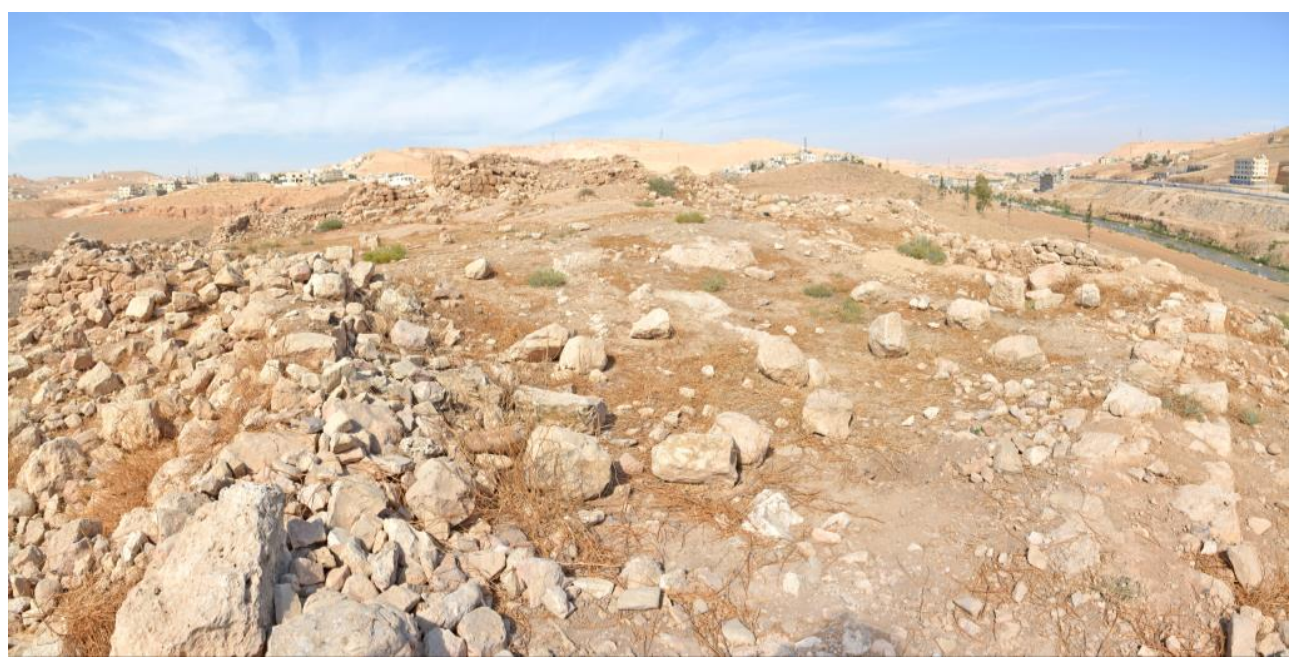

Fig. 6 - The razed remains of the khan and the Zarqa River on the right. 

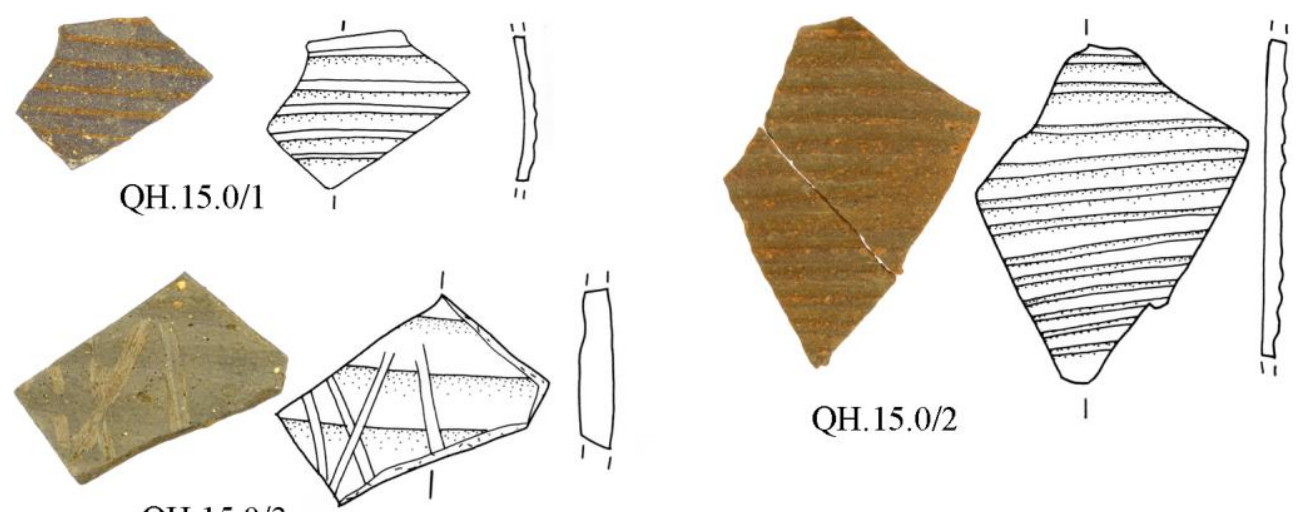

QH.15.0/3
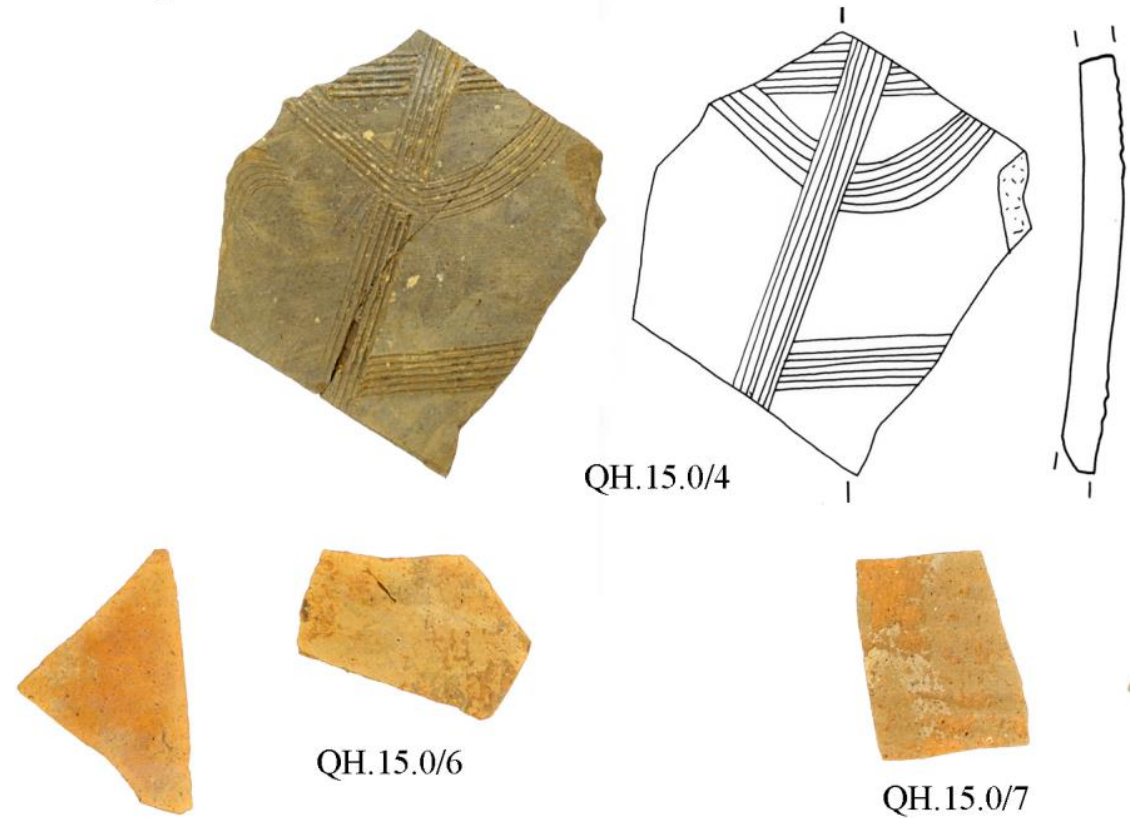

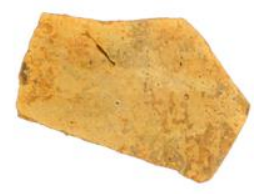

QH.15.0/6

QH.15.0/5

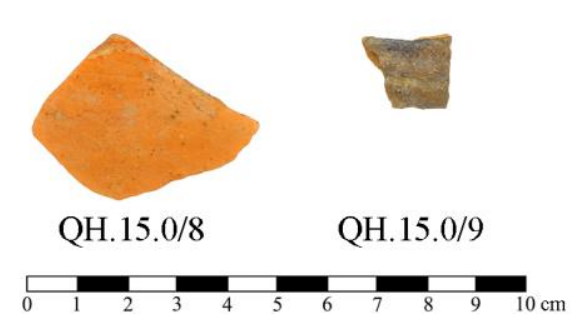

Fig. 7 - A selection of pottery collected in the site of Qalet Hamra during the survey of 2015. 


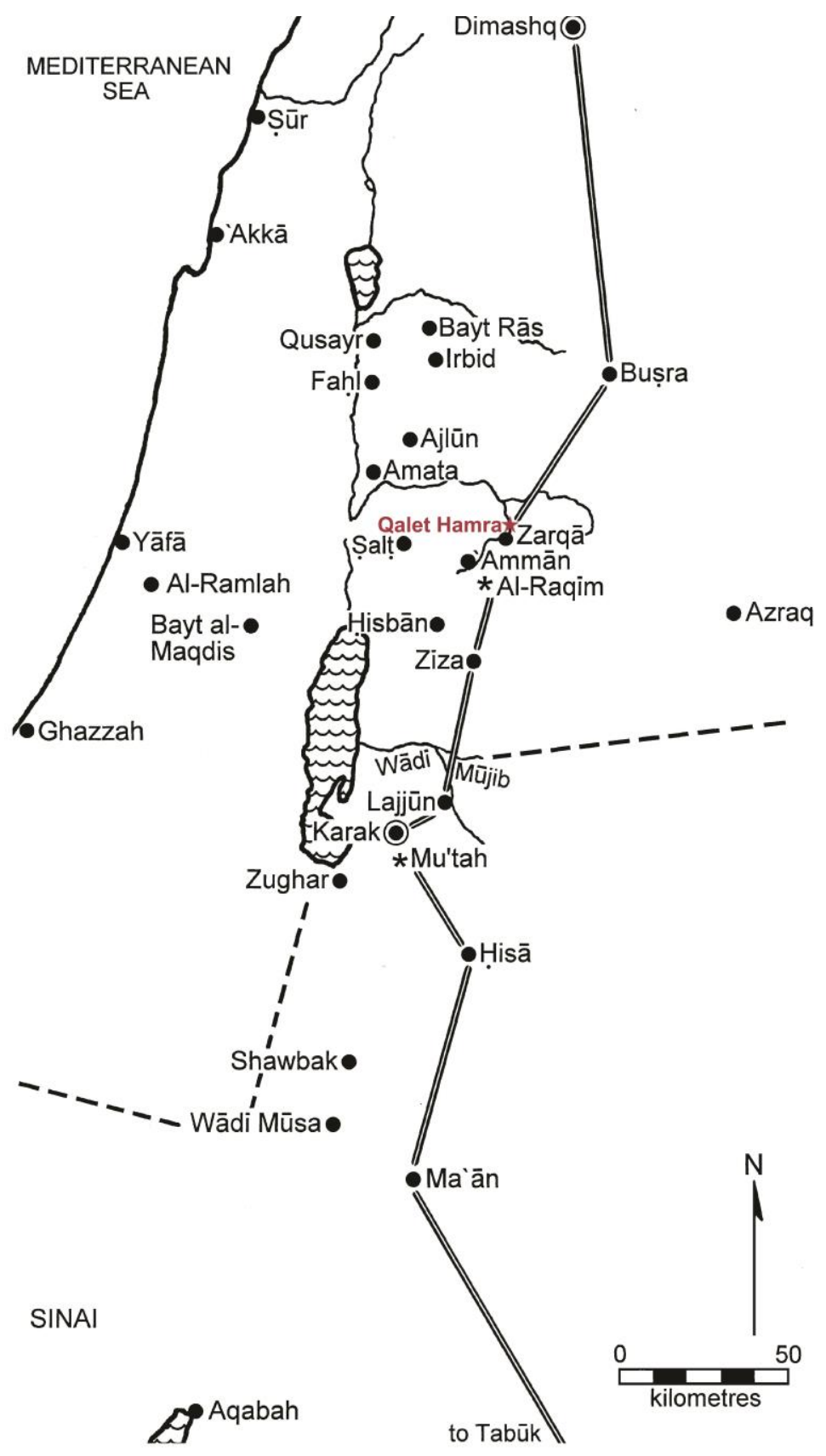

Fig. 8 - Map of Haji pilgrimage route in Mamluk period (after Walmsley 2001, fig. 15:4). 


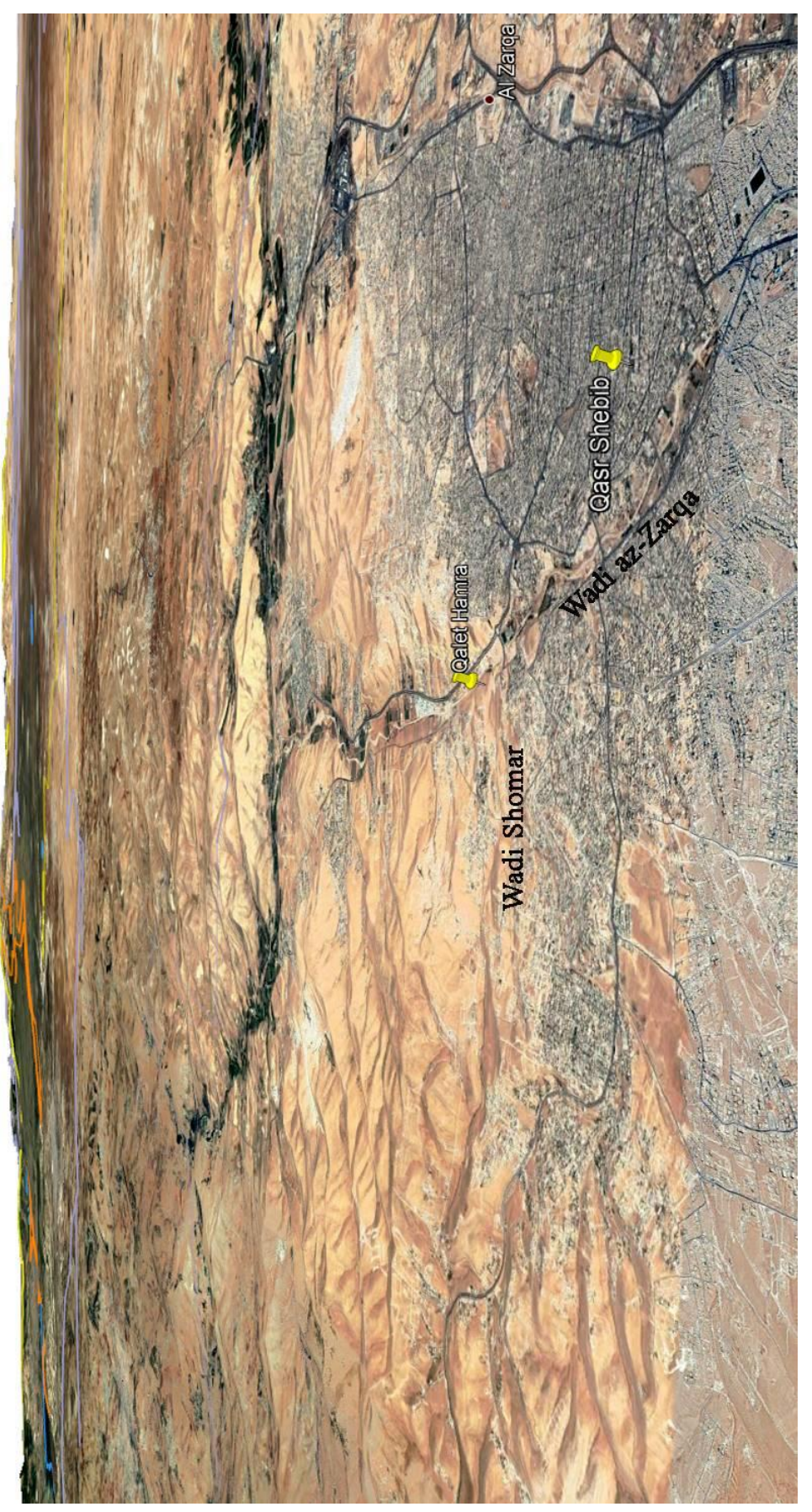

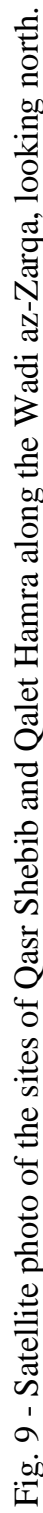

